\title{
Sosialisasi dan Pendampingan Pencegahan Penularan Covid 19 Dikalangan UMKM Untuk Meningkatkan Kepercayaan Konsumen di Kota Cimahi
}

\author{
Harun Heri Trismiyanto ${ }^{1}$, Ali Taufan ${ }^{2}$, Iing Nurdin ${ }^{3}$ \\ harun.heri@lecture.unjani.ac.id \\ Fakultas Kedokteran Universitas Jenderal Achmad Yani
}

\begin{abstract}
Abstrak
This article begins with the uniqueness and problems related to the socialization and assistance for preventing transmission of Covid 19 among small and medium micro-enterprises (MSMEs) in Cimahi City. It can be seen from Covid 19 transmission, which has not been completed until now. The purpose of the community is to provide socialization and assistance regarding the prevention of transmission of Covid 19 and the use of personal protective equipment in MSMEs in the city of Cimahi. The method used is descriptive-qualitative. It is sampling through purposive sampling. Secondary data collection techniques through regulations and the collection of primary data through observation and in-depth interviews to MSMEs in Cimahi City. This community service is conducted online through virtual media for training and offline, namely conducting face-to-face training directly by paying attention to health protocols. The validity of the data in this study was obtained by conducting credibility testing using triangulation as checking results from various sources of informants. The study results in this community service activity have similar perceptions in preventing transmission of Covid 19 in MSMEs that are more targeted by utilizing the Cimahi City MSME for prevention of Covid transmission 19.
\end{abstract}

Kata Kunci: Pandemi Covid 19, Sosialisasi, Pendampingan UMKM

\section{Pendahuluan}

Organisasi Kesehatan Dunia (WHO) mengumumkan bahwa penyakit Covid 19 sebagai pandemi (Sohrabi, et al., 2020), WHO juga menjelaskan bahwa dunia dalam keadaan darurat global akibat mewabahnya Covid-19 sejak Januari 2020 (Sebayang, 2020). Secara global, terhitung tanggal 21 April 2020 sebanyak 2.481.287 kasus terinfeksi COVID-19 di dunia, 170.436 orang meninggal dunia dan pasien yang telah sembuh sebanyak 646.854 orang (Worldometers, 2020). Saat ini di seluruh dunia, jumlah orang yang terkena dampak Covid-19 semakin meningkat dan jumlah kematian juga semakin banyak. Di Indonesia, diperkirakan jumlah kasus konsisten meningkat hingga mencapai angka kasus lebih dari 8.000 kasus dan angka maksimum jumlah kasus baru diperkirakan mencapai 600 kasus (Nuraini, 2020). Kondisi ini membuat pemerintah mengeluarkan status darurat bencana sampai 29 Mei 2020 terkait pandemi virus ini dengan jumlah waktu 91 hari (Koesmawardhani, 2020). Perilaku 
masyarakat yang tidak baik akan meningkatkan jumlah kasus infeksi dan jumlah kematian akibat terinfeksi virus Covid-19.

Di Indonesia, seluruh propinsi dinyatakan zona merah Covid-19, dan lebih dari 200 Kabupaten di Indonesia telah ditemukan penderita terinfeksi Covid-19. Jumlah orang terinfeksi Covid-19 di Indonesia terus bertambah. Tertanggal 21 April 2021 mencapai angka 1.620.569 orang. Untuk kasus yang sembuh sebanyak 1.475 .456 orang, sedangkan jumlah yang meninggal sebanyak 44.007 orang, Total Kasus Covid-19 di Kota Cimahi pada Selasa, 21 April 2021, mencapai 4.883. Merujuk pada covid19.cimahikota.go.id, sebanyak 313 pasien masih dalam perawatan.

Kota Cimahi diketahui saat ini kembali masuk zona oranye, setelah sempat zona kuning di Jabar. Kasus aktif Covid-19 terbanyak di Kota Cimahi kini ada di Kelurahan Cigugur Tengah dengan 39 kasus. Kasus sembuh di Cimahi sudah menyentuh 4.452, sedangkan kasus meninggal ada 118. Berikut daftar kelurahan dengan jumlah kasus positif aktif terbanyak per Selasa, 21 April 2021.

Akibat peningkatan jumlah kasus positif Covid-19 dan kematian akibat terinfeksi Covid-19, Presiden Republik Indonesia mengeluarkan Keputusan Presiden RI No.11 tahun 2020 tentang penetapan kedaruratan kesehatan masyarakat Corona virus disease 2019 (Covid-19) pada tanggal 31 Maret 2020. Kemudian Peraturan Pemerintah RI Nomor 21 tahun 2020 tentang pembatasan sosial berskala besar dalam rangka percepatan penanganan corona virus disease 2019 (Covid-19) pada tanggal 31 Maret 2020. Semua kebijakan pemerintah diarahkan untuk perubahan perilaku dalam pencegahan penularan Covid-19.

Kebijakan Pemerintah menginstruksikan masyarakat termasuk usaha kecil untuk melakukan Social Distancing dengan membatasi aktifitas keluar rumah, kegiatan sekolah dirumah, bekerja dari rumah (work from home), ibadah dirumah. Kebijakan lain dengan melakukan penutupan beberapa akses jalan dalam waktu tertentu, pembatasan jumlah transportasi, pembatasan jam operasional transportasi. Anjuran penggunaan masker bagi siapapun yang batuk dan pilek dengan tujuan untuk membatasi percikan droplet dari yang bersangkutan, menunda pertemuan-pertemuan dengan jumlah yang besar. Selain tetap melakukan pencegahan melalui upaya pola hidup bersih dan sehat dengan selalu mencuci tangan menggunakan sabun dengan air yang mengalir.

Usaha kecil saat ini harus tetap hidup sehingga ditengah covid ini tetap menjalankan usahanya, artinya terjadi interaksi antara pembeli dan penjual yang tidak bisa dihindari. Berdasarkan pengalaman dilapangan banyak usaha kecil dalam berinteraksi tidak memenuhi protokol Kesehatan contohnya banyak yang tidak menggunakan masker dan social Distancing ,kondisi ini sangat membahayakan bagi usaha kecil maupun masyarakat yang berinteraksi dengan mereka.

Permasalahan ini mendorong untuk digencarkannya sosialisasi mengenai pencegahan penularan Covid 19 Dan Penggunaan Alat Pelindung Diri. Berdasarkan hal ini maka kami tertarik untuk melakukan pengabdian kepada masyarakat dengan judul laporan "Sosialisai dan Pendampingan Pencegahan Penularan Covid 19 dikalangan UMKM untuk meningkatkan kepercayaan konsumen di Kota Cimahi."

Tujuan Kegiatan ini Pertama untuk membantu memulihkan kondisi usaha kecil di tengah pandemi covid 19, Kedua memberikan informasi dan fakta tentang COVID-19 dan penggunaan alat-alat Kesehatan, Ketiga Membantu mengurangi rasa takut dan khawatir para 
usaha kecil tentang bahaya covid 19 ini dan mendukung kemampuan mereka mengatasi dampak sekundernya dalam hidup mereka, Keempat untuk meningkatkan kesadaran akan perlunya dipatuhi Protokol Kesehatan sehingga usaha kecil dapat berpartisipasi secara optimal dalam penanggulangan-19 di Kota Cimahi

\section{Solusi Masalah}

Digitalisasi atau beralih ke pola perdagangan daring via marketplace menjadi satu solusi bagi Usaha Mikro Kecil dan Menengah untuk bertahan dan menopang perekonomian Indonesia di tengah pandemi Covid-19 seperti sekarang ini. Digitalisasi telah menjadi sesuatu yang tidak terelakkan sekaligus menjadi salah satu solusi bagi para Usaha Mikro Kecil dan Menengah yang jumlahnya cukup besar di Kota Cimahi.

Digitalisasi ini jadi tidak terelakkan, jadi kita dipaksa untuk melakukannya secara digital. Untuk itu, kami tak meninggalkan Usaha Mikro Kecil dan Menengah untuk melakukan (transisi ini) sendiri, telah membuat sejumlah insentif guna mendorong para pelaku bisnis kecil ini untuk dapat beralih dan bersaing di pasar online dan offline.

Workshop ini sudah dilakukan saat terjadi pandemi maupun sebelumnya, sudah dicoba dilakukan penguatan Usaha Mikro Kecil dan Menengah lewat pelatihan, standarisasi, sertifikasi, agar dapat laku di pasar online. Inisiasi tersebut tak hanya agar para pebisnis UMKM di Kota Cimahi ini mau membuat tokonya di marketplace, namun juga di beberapa komunitas dan aplikasi lokal lainnya. Terdapat dukungan promosi dan pemasaran online dan Offline yang juga diperkuat, seperti dengan adanya katalog digital, yang bisa langsung menghubungkan konsumen ke produsennya.

Sementara dari sisi marketplace, Tokopedia, setuju bahwa saat ini UMKM telah bertransisi ke wadah digital dan daring.

Hal ini terbukti dengan naiknya mitra merchant di Tokopedia hingga tiga kali lipat selama masa pandemi.

Atas dasar permasalahan di atas maka peneliti memberikan solusi sebagai berikut :

a. Memberikan pemahaman terkait pengalaman berwirausaha melalui media digital dimasa krisis ini.

b. Memberikan pemahaman cara menciptakan/menumbuhkan mental yang kuat sebagai wirausaha sukses meskipun ditengah kondisi krisis.

c. Memberikan pengetahuan dan informasi mengenai Covid 19.

Langkah-langkah dalam melaksanakan solusi dari permasalahan mitra adalah:

a. Memberikan bimbingan arahan berupa pelatihan terkait pengalaman berwirausaha melalui media digital dimasa krisis.

b. Memberikan bimbingan dan arahan menciptakan/menumbuhkan mental yang kuat sebagai wirausaha sukses meskipun ditengah kondisi krisis.

\section{Metode Pelaksanaan}

Metode pelaksanaan kegiatan Pengabdian Kepada Masyarakat menjelaskan tahapan dalam melaksanakan solusi yang ditawarkan untuk mengatasi permasalahan yang memuat hal-hal berikut ini : 
Vol. 2 No. 2, Juli-Desember 2021

1. Pihak-pihak yang terlibat dalam kegiatan Pengabdian Kepada Masyarakat.

Pihak-pihak yang terlibat dalam Pengabdian Masyarakat terdiri UMKM Kota Cimahi, Dinas Koperasi dan UMKM Kota Cimahi, TV. Harmoni, Kamar Dagang dan Industri Kota Cimahi serta Dosen Fakultas Kedokteran Unjani.

2. Metode dan tahapan dalam kegiatan pengabdian kepada masyarakat, mulai dari indentifikasi kebutuhan masyarakat, perancangan, pembuatan, uji operasi, pendampingan operasional, hingga diseminasi hasil penelitian/teknologi tersebut kepada masyarakat/mitra.

Berdasarkan permasalahan yang ada pada mitra, maka PKM ini dilaksanakan untuk memberikan informasi dan pemahaman terkait Sosialisai dan Pendampingan Pencegahan Penularan Covid 19 dikalangan UMKM untuk meningkatkan kepercayaan konsumen di Kota Cimahi.

Langkah-langkah dalam melaksanakan solusi dari permasalahan mitra.

Langkah-langkah dalam melaksanakan solusi untuk pemecahan masalah mitra ini yaitu melakukan workshop melalui media online dan offline.

Workshop merupakan suatu metode yang dilakukan untuk memberikan pemahaman ilmu pengetahuan dan keterampilan mengenai Sosialisai dan Pendampingan Pencegahan Penularan Covid 19 dikalangan UMKM untuk meningkatkan kepercayaan konsumen di Kota Cimahi.

\section{Hasil Pelaksanaan}

Usaha mikro kecil dan Mengenah (UMKM) di Kota Cimahi memiliki berbagai macam keunikan dari jenis kegiatan usahanya, baik yang aktual maupun yang masih potensial. Namun, permasalahan khusus dalam Memberikan pemahaman terkait pengalaman berwirausaha melalui media digital dimasa krisis ini, memberikan pemahaman cara menciptakan/menumbuhkan mental yang kuat sebagai wirausaha sukses meskipun ditengah kondisi krisis, memberikan pengetahuan dan informasi mengenai Sosialisai dan Pendampingan Pencegahan Penularan Covid 19 dikalangan UMKM untuk meningkatkan kepercayaan konsumen di Kota Cimahi.
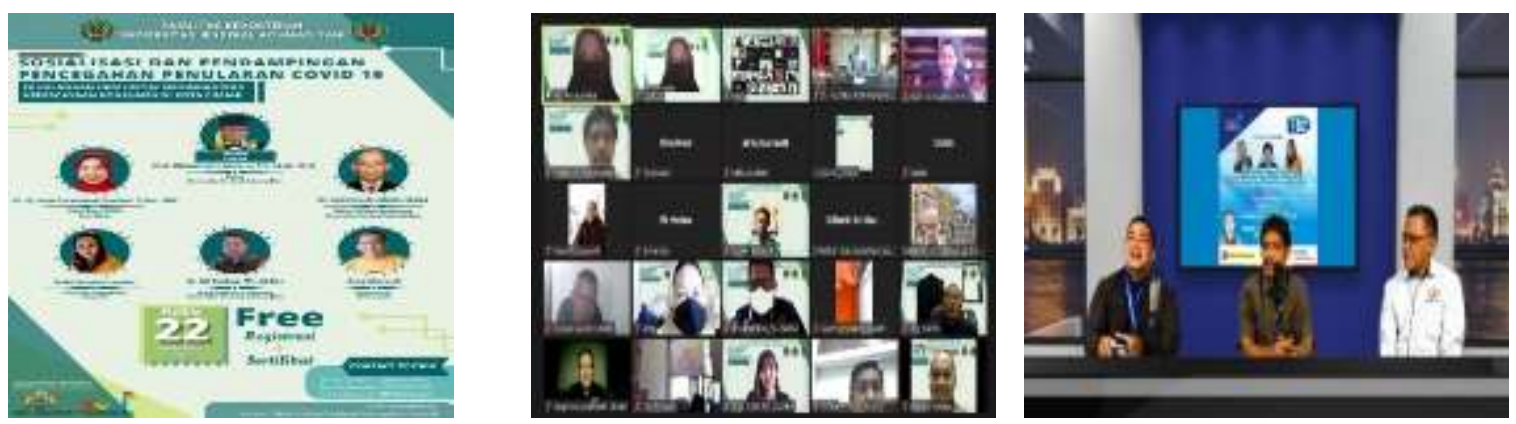

Gambar 1. Penyuluhan Sosialisasi Dan Pendampingan Pencegahan Penularan Covid 19 Binaan Kadin Kota Cimahi

Seperti yang dikemukakan pada Pendahuluan, Penyuluhan Sosialisasi Dan Pendampingan Pencegahan Penularan Covid 19 Binaan Kadin Kota Cimahi ini difokuskan pada UMKM di 
Kota Cimahi. Namun tampaknya belum tertata sehingga kemungkinan belum tepat guna dan tepat sasaran, khususnya dengan adanya masa Pandemi Covid-19 ini.

Berdasarkan permasalahan yang ada pada mitra, maka PKM ini bertujuan untuk memberikan informasi dan pemahaman terkait Sosialisasi pencegahan Penularan Covid 19 Dan Penggunaan Alat Pelindung Diri Pada Usaha Kecil Kota Cimahi. Langkah-langkah dalam melaksanakan solusi untuk pemecahan masalah mitra ini yaitu melakukan workshop melalui media online.

Workshop merupakan suatu metode yang dilakukan untuk memberikan Pendampingan yang diberikan kepada UMKM di Kota Cimahi diawali dengan aspek latar belakang usaha guna mengetahui dasar gagasan usaha seperti prospek pasar, manfaat ekonomi, manfaat sosial dan daftar riwayat hidup dari pelaku UMKM. Aspek pemasokan sebagai pasar input, dan aspek pemasaran sebagai pasar output dapat memberikan gambaran umum penentuan wilayah pemasaran, dari cakupan wilayah pasar terkecil hingga yang lebih luas. Permintaan pasar juga perlu diprediksi untuk memperkirakan pembeli potensial dengan asumsi permintaan pasar dari target yang ditentukan. Disamping itu menentukan segmen dan target pasar yang tepat, dan memproyeksikan permintaan penjualan selama 3 tahun dari tahun 2021 sampai dengan tahun 2023.

Pada kegiatan webinar yang diisi oleh tiga narasumber utama yang terdiri dari satu narasumber dari akademisi dan dua narasumber dari praktisi UMKM dimana kegiatan berlangsung selama kurang lebih tiga jam memberikan informasi yang riil terkait kondisi perkembangan UMKM saat ini khususnya di Kota Cimahi. Para peserta webinar yang merupakan pelaku UMKM di Kota Cimahi juga sangat aktif dalam memberikan tanggapan dan berbagi informasi terkait kondisi usaha mereka selama masa pandemi, sehingga kegiatan ini menjadi wadah untuk saling berbagi informasi serta strategi untuk mempertahankan usaha di masa pandemi covid-19 ini.

\section{Kesimpulan}

Kegiatan pengabdian kepada masyarakat yang dilaksanakan oleh Dosen Fakultas Kedokteran Universitas Jenderal Achmad Yani yang bertajuk Sosialisasi pendampingan dan pencegahan penularan covid 19 di kalangan UMKM di Kota Cimahi dimana topik tersebut disesuaikan dengan bidang ilmu kedokteran. Informasi yang dirangkum dalam video merupakan informasi yang dianggap diperlukan oleh pelaku UMKM, khususnya di masa pandemi Covid- 19.

Umpan balik peserta webinar terkait pelaksanaan webinar dan video pelatihan yang dihasilkan dalam kegiatan ini adalah sangat baik. Sebagian besar peserta yang menjadi responden menyatakan bahwa tema dan isi materi serta informasi yang dibagikan dalam video dan selama webinar dapat menambahkan informasi bagi mereka dalam mempertahankan dan mengembangkan usaha di masa pandemi Covid-19. Video dan materi webinar yang disajikan sudah sangat sesuai dengan kebutuhan informasi para pelaku UMKM di Kota Cimahi dalam menghadapi tantangan perkembangan usaha selama pandemi. Sehingga kedepannya diharapkan dapat diadakan kegiatan sejenis yang dapat menjadi wadah bagi para pelaku UMKM dalam berbagi informasi dan pengetahuan terkait pengembangan usaha. 


\section{Daftar Pustaka}

A. R., Nuraini, A., Elisa, K., \& Iman, S. (2020). Faktor-Faktor Psikososial dari Ketidakpatuhan Masyarakat pada Masa Pandemik. Artikel, 19, 1-10.

Capri, A. (2019). Micro And Small Businesses In Indonesia's Digital Economy Keys To Developing New Skills And Human Capital. Jakarta: The Asia Pacific Foundation Of Canada.

Gugus Tugas COVID-19. (2020). Peta Sebaran Data COVID-19[Online]. Diakses pada tanggal 3 Juni $2020 \mathrm{WIB}$ pukul 12.05 dari https://covid19.cimahikota.go.id/peta

Koesmawardhani, N. W. (2020, Maret 17). Pemerintah Tetapkan Masa Darurat Bencana Corona hingga 29 Mei 2020. Detiknews. Diunduh dari https://news.detik.com/berita/d-4942327/pemerintah-tetapkan-masa-darurat-bencanacorona-hingga-29-mei-2020.

Sohrabi, C., Alsafi, Z., O'Neil, N., Khan, M., Kerwan, A., Al-Jabir, A., Aghad, R. (2020). World Health Organization declares global emergency: A review of the 2019 novel coronavirus (COVID-19) . International Journal of Surgery.

Undang-Undang Nomor 20 Tahun 2008 Tentang Usaha Mikro, Kecil, dan Menengah Bab VI Pasal 20

Worldometers. (2020, Maret 15). COVID-19 CORONAVIRUS PANDEMIC. Dipetik Mei 15, 2020 dari Worldometers.info: https://www.worldometers.info/coronavirus/.

\section{Copyrights}

Copyright for this article is retained by the author(s), with first publication rights granted to the journal.

This is an open-access article distributed under the terms and conditions of the Creative Commons Attribution license (http://creativecommons.org/licenses/by/4.0/) 